\title{
Uma evangelização para a Amazônia
}

An evangelization for the Amazon

"Eu vi, eu vi a miséria do meu povo que está no Egito. Ouvi seu grito por causa dos seus opressores; pois eu conheço as suas angústias. Por isso desci a fim de libertá-lo da mão dos egípcios, $e$ para fazê-lo subir desta terra para uma terra boa e vasta, terra que mana leite e mel." "2. Ao longo da história da salvação tivemos a presença de Deus na longa caminhada humana por este mundo e interagindo, pois Deus vê, escuta e age diante de uma realidade na qual há a necessidade primária do seu povo: poder existir acompanhado de seus direitos à liberdade " $A$ verdadeira liberdade, porém, é um sinal eminente da imagem de Deus no homem [...]"3, e à terra que Ele lhes ofereceu; "Deus destinou a terra, com tudo que ela contém, para uso de todos os homens e povos, de tal modo que os bens criados devem bastar a todos, com equidade, sob as regras da justiça, inseparável da caridade. ". ${ }^{4}$

Com os dons do Espírito Santo, todos somos convocados a sermos senhores cuidadores de toda a criação "Que eles dominem

\footnotetext{
${ }^{1}$ Formado em filosofia pela Faculdade São Luiz, teologia pela FACASC, especialização em Counseling pelo IATES, Mestrando em Direito Canônico pelo ISDCSC.

${ }^{2}$ BÍBLIA DE JERUSALÉM. Êxodo 3,7-8.

${ }^{3}$ CONCÍLIO VATICANO II. Constituição pastoral gaudium et spes, n. 17.

${ }^{4}$ CONCÍLIO VATICANO II. Constituição pastoral gaudium et spes, n. 69.
} 
sobre os peixes do mar, as aves do céu, os animais domésticos, todas as feras e todos os répteis que rastejam sobre a terra."5.

Nesse sentido, na sua nova Exortação Apostólica Pós-Sinodal "Querida Amazônia", direcionada ao povo de Deus e a todas as pessoas de boa vontade, o Papa Francisco aponta sua preocupação pelos direitos dos povos nativos, dos mais pobres e dos últimos e esquecidos pelos sistemas políticos e sociais que há anos vêm engajado em outros propósitos, excluindo a dignidade das pessoas "temos graves violações dos direitos humanos e novas escravidões que atingem especialmente as mulheres, a praga do narcotráfico que procura submeter os indígenas, ou o tráfico de pessoas que se aproveita daqueles que foram expulsos de seu contexto cultural." 6 .

Ainda, ressalta sobre a atenção redobrada que se deve ter na proteção das florestas, vegetação, todas as formas de vida animal e os rios, águas que trazem a subsistência para os indígenas e ribeirinhos que vivem da pesca e da caça. "Quando se elimina a floresta, esta não é substituida, ficando um terreno com poucos nutrientes que se transforma num território desértico ou pobre em vegetação. Isto é grave, porque, nas entranhas da floresta amazônica, subsistem inúmeros recursos que poderiam ser indispensáveis para a cura de doenças. Os seus peixes, frutos e outros dons sobreabundantes enriquecem a alimentação humana."” .

O Santo Padre aponta, na Exortação Apostólica, o cuidado com a preservação da própria riqueza cultural daquela região que, aos poucos, é tomada pela transculturação que desvaloriza aquele tesouro nativo; ao invés, a proposta é a inculturação, diz, ainda: "A Igreja precisa de escutar a sua sabedoria ancestral, voltar a dar voz aos idosos,

\footnotetext{
${ }^{5}$ BÍBLIA DE JERUSALÉM. Gênesis 1,26.

${ }^{6}$ FRANCISCO. Exortação apostólica pós-sinodal "Querida Amazônia”, 02 fev. 2020, n. 14.

${ }^{7}$ FRANCISCO. Exortação apostólica pós-sinodal "Querida Amazônia”, 02 fev. 2020, n. 48.
} 
reconhecer os valores presentes no estilo de vida das comunidades nativas, recuperar a tempo as preciosas narrações dos povos.".

E, por fim, o Papa sonha com comunidades cristãs encarnadas na Amazônia, dando à Igreja um rosto novo com traços amazônicos, "O caminho continua e o trabalho missionário, se quiser desenvolver uma Igreja com rosto amazônico, precisa de crescer numa cultura do encontro rumo a uma 'harmonia pluriforme".. .

Diante do exposto, o que quer o santo padre com esse sonho? A princípio, que a Igreja jamais se esqueça dos pobres e pequeninos, ainda desconhecedores do querigma, e, num segundo momento, que o Espírito Santo sopre sobre a Vida Consagrada para empenhar-se e unir-se em verdadeira e fervorosa comunhão, a fim de tornar mais efetiva a ação missionária.

Aqui, nos cabe saber o que é a Vida Consagrada e o que diz o Código de Direito Canônico: “A vida consagrada pela profissão dos conselhos evangélicos é a forma estável de viver pela qual os fiéis, sob a ação do Espírito Santo, seguindo a Cristo mais de perto, se consagram totalmente a Deus sumamente amado, para que, dedicados por um título novo e peculiar à Sua honra, à edificação da Igreja e à salvação do mundo, alcancem a perfeição da caridade ao serviço do Reino de Deus e, convertidos em sinal preclaro na Igreja, preanunciem a glória celeste."10. Os fiéis que desejarem viver segundo a ação do Espírito Santo, com clareza de que o fundamento da sua vida é Jesus Cristo, com acento especial nos Conselhos Evangélicos, que não se restringem apenas à castidade, à pobreza e à obediência, mas à vida fraterna, à oração e ao amor para com todos, podem buscar essa nova forma de vida.

Uma luz que se aponta o alvorecer missionário, a partir da exortação, são as novas formas de Vida Consagrada que, nas últimas décadas, têm surgido como um sopro do Espírito Santo sobre a nossa

\footnotetext{
${ }^{8}$ Ibid., n. 70.

${ }^{9}$ Ibid., n. 61.

${ }^{10}$ CONCÍLIO VATICANO II. Código de direito canônico, cânon 573, §1.
} 
realidade eclesial e que a cada tempo cresce, encanta e compromete jovens e adultos de todos os lugares, com sede de Deus e, ao mesmo tempo, saudáveis e alegres, com uma coragem renovadora para anunciar o evangelho.

Outra forma que ainda precisa ser reavaliada com profunda reflexão é o que nos pede o santo padre nas entrelinhas da exortação, "A vida consagrada, capaz de diálogo, síntese, encarnação e profecia, ocupa um lugar especial nesta configuração plural e harmoniosa da Igreja amazônica. Mas faz-lhes falta um novo esforço de inculturação, que ponha em jogo a criatividade, a audácia missionária, a sensibilidade e a força peculiar da vida comunitária."11. As Congregações e Ordens religiosas deverão parar, sentar-se mais vezes juntos e, numa rica roda de troca de experiências, vivenciar o Evangelho; não mais como estruturas isoladas, buscando, assim, uma nova forma de evangelização.

Por último, cabe-nos fazer memória da Virgem Maria, que cheia do Espírito Santo e após ter recebido o anúncio do anjo, caminhou missionariamente até a casa de sua prima Isabel para levar o Verbo encarnado e oferecer ajuda: aquilo que o seu coração e as suas mãos poderiam fazer. Temos na Santíssima Virgem o primeiro modelo cristão de evangelizador e evangelização; após seu 'sim', ela tudo fez para que o Projeto de Salvação se tornasse cada vez mais concreto. Outros são os genuínos missionários, os discípulos do Senhor, os apóstolos e os primeiros padres. Com inspiração do testemunho da Igreja nascente, alimentamos em sonhos e em atos o Evangelho do Senhor para a Amazônia.

${ }^{11}$ FRANCISCO. Exortação apostólica pós-sinodal "Querida Amazônia", 02 fev. 2020, n. 70. 